\title{
Temporal Changes in Linezolid Minimum Inhibitory Concentration Values in Vancomycin-resistant Enterococci and Methicillin- resistant Staphylococcus aureus Strains
}

\author{
Vankomisine Dirençli Enterokok ve Metisiline Dirençli Staphylococcus aureus Suşlarında \\ Linezolid Minimum Inhibitör Konsantrasyon Değerlerinin Yıllar Içinde Değişimi
}

\author{
(1) Serpil GENÇ11, (1) Fatma Zehra DUYMAZ2 , (1) Devrim DÜNDAR²

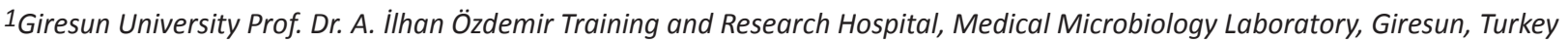 \\ ${ }^{2}$ Kocaeli University Faculty of Medicine, Department of Medical Microbiology, Izmit, Turkey
}

\section{Abstract}

Introduction: Vancomycin-resistant enterococci (VRE) and methicillin-resistant Staphylococcus aureus (MRSA) infections are among the most common Gram-positive nosocomial infections. These isolates are resistant to most antibiotics, limiting the antibiotic options that can be used in treatment and causing treatment failure. Linezolid is an important option in the treatment of resistant Gram-positive infections, and came into use in Turkey in 2006. Linezolid-resistant Enterococci and Staphylococcus strains are rarely reported worldwide. The aim of this study was to investigate whether there was an increase in linezolid minimum inhibitory concentration (MIC) values in VRE and MRSA isolates over time.

Materials and Methods: Thirteen VRE and 20 MRSA isolates from 2005-2009 (group 1), 18 VRE and 20 MRSA isolates from 2013-2014 (group 2), and seven VRE and 27 MRSA isolates from 2017-2018 (group 3) obtained from various clinical samples at Kocaeli University Medical Faculty Hospital were included in the study. The linezolid MIC values of the isolates were determined by broth microdilution method. The results were interpreted according to the European Committee on Antimicrobial Susceptibility Testing standards.

Results: All of the VRE and MRSA isolates were susceptible to linezolid. Linezolid $\mathrm{MIC}_{50}$ and $\mathrm{MIC}_{90}$ values were $2 \mathrm{mg} / \mathrm{l}$ in VRE isolates in all three groups. In MRSA isolates, $\mathrm{MIC}_{50}$ was $2 \mathrm{mg} / \mathrm{l}$ in group 1, and $4 \mathrm{mg} / \mathrm{l}$ in groups 2 and 3, while $\mathrm{MIC}_{90}$ was $4 \mathrm{mg} / \mathrm{l}$ in all groups.

Conclusion: Global rates of linezolid resistance has been reported to be $<1 \%$ for $\mathrm{S}$. aureus and VRE. There were no linezolid-resistant isolates in this study. However, we detected a significant increase in $\mathrm{MIC}_{50}$ and $\mathrm{MIC}_{90}$ values compared to most earlier studies performed in Turkey. This increase is expected due to the widespread use of linezolid over the years. The principles of rational antibiotic use should be applied to maintain the low resistance rates to linezolid, which is one of the few remaining options for the treatment of multidrug-resistant Gram-positive infections.

Keywords: Epidemiology, glycopeptides

Öz

Giriş: Vankomisine dirençli enterokok (VRE) ve metisiline dirençli Staphylococcus aureus (MRSA) enfeksiyonları Gram-olumlu hastane enfeksiyonları arasında ilk sıralarda yer almaktadır. Bu izolatların çoğunun antibiyotiğe dirençli olması, tedavide kullanılabilecek antibiyotik seçeneklerini kısıtlamakta ve tedavi başarısızlığını beraberinde getirmektedir. Dirençli Gram-olumlu enfeksiyonların tedavisinde önemli bir seçenek olan linezolid, Türkiye'de 2006 yılında kullanıma girmiştir. Dünyada nadiren de olsa, linezolid dirençli enterokok ve stafilokok suşları bildirilmektedir. Bu çalışmada VRE ve MRSA izolatlarında linezolid minimum inhibitör konsantrasyonu (MiK) değerlerinde yıllar içerisinde artış olup olmadığının araştırılması amaçlanmıştır.

Cite this article as: Genç S, Duymaz FZ, Dündar D. Temporal Changes in Linezolid Minimum Inhibitory Concentration Values in Vancomycin-resistant Enterococci and Methicillin-resistant Staphylococcus aureus Strains. Mediterr J Infect Microb Antimicrob. 2019;8:6.

Address for Correspondence/Yazışma Adresi: Serpil Genç MD, Giresun University Prof. Dr. A. İlhan Özdemir Training and Research Hospital, Medical Microbiology Laboratory, Giresun, Turkey Phone: +90 5443013230 E-mail: metin.serpil@yahoo.com

Received/Geliş Tarihi: 11.12.2018 Accepted/Kabul Tarihi: 14.03.2019 ORCID ID: orcid.org/0000-0001-5399-3374

๑Copyright 2019 by the Infectious Diseases and Clinical Microbiology Specialty Society of Turkey

Mediterranean Journal of Infection, Microbes and Antimicrobials published by Galenos Yayınevi.
Published in: This research has been presented as a poster at XXXVI. Turkish Microbiology Congress in which organized between 12-16 November 2014 at Belek, Antalya.

Published: 26 March 2019 
Gereç ve Yöntem: Kocaeli Üniversitesi Tıp Fakültesi Hastanesi'nde çeşitli klinik örneklerden izole edilmiş 2005-2009 (grup 1) yıllarından 13 VRE, 20 MRSA, 2013-2014 (grup 2) yıllarından 18 VRE, 20 MRSA ve 2017-2018 (grup 3) yıllarından yedi VRE, 27 MRSA izolatının, linezolid MiK değerleri sıvı mikrodilüsyon yöntemiyle belirlenmiştir. Sonuçlar European Committee on Antimicrobial Susceptibility Testing standartlarına göre yorumlanmıştır. Bulgular: VRE ve MRSA izolatlarının hepsi linezolide duyarlı bulunmuştur. Her üç gruptaki VRE izolatlarında linezolid MiK $_{50}$ ve MiK $\mathrm{K}_{90}$ değeri 2 mg/l olarak saptanmıştır. Metisiline dirençli Staphylococcus aureus izolatlarında ise Mik so değeri grup 1 de 2 mg/l, diğer gruplarda 4 mg/l bulunurken, MiK $_{90}$ değeri tüm izolatlarda $4 \mathrm{mg} / \mathrm{l}$ bulunmuştur.

Sonuç: Yapılan çalışmalarda, dünya genelinde linezolid direnci S. aureus ve VRE için <\%1 olarak bildirilmiştir. Bu çalışmada da linezolide dirençli izolat tanımlanmamış, MiK $_{50}$ ve MiK $_{90}$ değerlerinde, ülkemizde farklı tarihlerde yapılmış çoğu çalışmaya göre belirgin bir artış olduğu gözlenmiştir. Bu artış, linezolid kullanımının yıllar içinde yaygınlaşması ile beklenen bir durumdur. Linezolid, halen dirençli Gram-olumlu enfeksiyonların tedavisindeki önemli seçeneklerden biridir. Akılcı kullanım ve antibiyotik duyarlılık verilerinin yakın takibi ile direnç gelişiminin önüne geçilerek duyarlılı̆ının devamı sağlanmalıdır.

Anahtar Kelimeler: Epidemiyoloji, glikopeptitler

\section{Introduction}

Staphylococci and enterococci are the two leading causes of Gram-positive nosocomial infections ${ }^{[1-37]}$. Multidrug resistance in vancomycin-resistant enterococci (VRE) and methicillinresistant Staphylococcus aureus (MRSA) strains limit the agents that can be used in the treatment of infections caused by these bacteria. Linezolid is an effective and important alternative for treating resistant Gram-positive microorganisms such as MRSA, VRE, and penicillin-resistant Streptococcus pneumoniae. Linezolid became available in Turkey in $2006^{[2-4]}$.

Since its introduction into clinical use, isolates with reduced sensitivity to linezolid have been reported worldwide, including Turkey. According to global surveillance data, linezolid sensitivity in staphylococci (including MRSA) and enterococci (including VRE) is $>99 \% 0^{[5]}$. According to the national surveillance data from Turkey, rates of linezolid resistance were reported to be $0-2.3 \%$ in $S$. aureus and $<1 \%$ in enterococci ${ }^{[6,7]}$.

This study was conducted to investigate whether linezolid minimum inhibitor concentration (MIC) values have increased in VRE and MRSA isolates over time.

\section{Materials and Methods}

A total of 38 VRE and 67 MRSA isolates obtained from various clinical samples in the Kocaeli University Faculty of Medicine Hospital were included in the study. In order to better observe temporal changes in MIC, the isolates were divided into three groups, with the oldest deep-frozen isolates that we could access included in the first group: group 1 (2005-2009), group 2 (2013-2014), and group 3 (2017-2018). In total, 13 VRE and 20 MRSA strains from group 1, 18 VRE and 20 MRSA strains from group 2, and seven VRE and 27 MRSA strains from group 3 were included in the study.

Strains that had previously undergone species-level identification and susceptibility testing in a VITEK 2 (bioMérieux, France) system prior to storage at $-80{ }^{\circ} \mathrm{C}$ were removed from storage and passaged twice.
Using the disc diffusion method, vancomycin resistance was determined in enterococcus isolates grown in pure culture using $5 \mu \mathrm{g}$ vancomycin disc (0xoid, UK), whereas in S. aureus isolates, methicillin resistance was determined using $30 \mu \mathrm{g}$ cefoxitin (Oxoid, UK) disc. In accordance with European Committee on Antimicrobial Susceptibility Testing (EUCAST) recommendations, enterococci with inhibition zone diameter $<12 \mathrm{~mm}$ were considered to be VRE and $S$. aureus isolates with zone diameter $<22 \mathrm{~mm}$ were considered to be $\mathrm{MRSA}^{[8]}$.

Linezolid MIC values of the MRSA and VRE isolates were identified using the broth microdilution method. For this purpose, bacterial suspensions with turbidity equivalent to McFarland 0.5 standard were prepared using colonies in fresh bacterial culture. Cation-adjusted Mueller-Hinton broth was placed in sterile, round bottom plates. Serial two-fold dilutions were performed to yield antibiotic concentrations from 0.0625 to $32 \mathrm{mg} / \mathrm{l}$. Bacterial suspension was then added to the wells of antibiotic solution to make the final concentration of inoculum $5 \times 10^{5}$ colony-forming units $/ \mathrm{ml}$, and the plates were incubated at $35{ }^{\circ} \mathrm{C}$ for 18 hours. The lowest antibiotic concentration at which there was no visible growth was accepted as the MIC value. E. faecalis ATCC 29212 and S. aureus 29213 were used as control strains. Based on EUCAST standards, isolates of both species with a linezolid MIC value $\leq 4 \mathrm{mg} / \mathrm{L}$ were considered to be susceptible ${ }^{[8,9]}$.

\section{Results}

Thirty-four of the MRSA isolates originated from skin and soft tissue samples, 12 from respiratory system samples, 12 from catheters, six from sterile body fluid, and three from urine. Seventeen of the VRE isolates originated from urine, 16 from soft tissue, one from the respiratory system, two from sterile body fluid, one from catheter, and one from stool sample (Table 1).

All of the VRE and MRSA isolates were found to be susceptible to linezolid. Linezolid $\mathrm{MIC}_{50}$ and $\mathrm{MIC}_{90}$ values of VRE isolates were $2 \mathrm{mg} / \mathrm{l}$ in all three groups. The $\mathrm{MIC}_{50}$ value of MRSA isolates was $2 \mathrm{mg} / \mathrm{l}$ in group 1 and $4 \mathrm{mg} / \mathrm{l}$ in groups 2 and 3, while $\mathrm{MIC}_{90}$ was $4 \mathrm{mg} / \mathrm{l}$ in all isolates (Table 2). 


\section{Discussion}

Data from the Healthcare-Associated Infections Surveillance Network of Turkey (HAl-net) indicate that in 2015, 2016, and 2017, VRE accounted for $14.3 \%, 13.33 \%$, and $12.17 \%$ of enterococci isolates that caused hospital infection and $39.15 \%, 38.83 \%$, and $37.43 \%$ of $S$. aureus isolates were MRSA, respectively. Although resistance rates have shown a downward trend over the years, proportions of MRSA (37.43\%) and VRE $(12.17 \%)$ are very high according to the most recent data ${ }^{[10-}$ ${ }^{12]}$. Multidrug-resistant isolates such as VRE and MRSA comprise a major problem in the treatment of infections they cause. Linezolid is one of very few antibiotics that can effectively treat these infections ${ }^{[3,13]}$.

One year after linezolid became clinically available, the first linezolid-resistant S. aureus isolate was reported from the United States in a patient treated with linezolid for one month ${ }^{[14]}$. In the following years, reports of linezolid-resistant MRSA and VRE isolates continued ${ }^{[2,15,16]}$. The detection of linezolid-resistant isolates after linezolid use in particular is noteworthy ${ }^{[14,17-19]}$. In a study investigating risk factors associated with 48 VRE isolates with reduced linezolid susceptibility isolated over a period of eight years, Santayana et al. ${ }^{[20]}$ identified linezolid use in the past year as an independent risk factor (OR: 31.84).
According to 2014 data from an American surveillance program monitoring linezolid resistance, three MRSA and six VRE isolates were reported to be resistant to linezolid. The authors stated that resistance was unchanged from previous years, with $\mathrm{MIC}_{50}$ and $\mathrm{MIC}_{90}$ values of $1 \mathrm{mg} / \mathrm{l}$ for both MRSA and VRE isolates ${ }^{[21]}$. In their 2009 study, Efe et al. ${ }^{[22]}$ determined that linezolid $\mathrm{MIC}_{50}$ and $\mathrm{MIC}_{90}$ were $1.5 \mathrm{mg} / \mathrm{l}$ and $2 \mathrm{mg} / \mathrm{l}$ in MRSA and $0.75 \mathrm{mg} / \mathrm{l}$ and $1.5 \mathrm{mg} / \mathrm{l}$ in VRE, respectively.

In a multicenter study examining linezolid susceptibility, $0.01 \%$ of 18,527 S. aureus strains were found to be resistant ${ }^{[4]}$. An outbreak of linezolid-resistant S. aureus was reported in an intensive care unit in Madrid ${ }^{[16]}$. Morales et al. ${ }^{[23]}$ reported another outbreak of linezolid-resistant MRSA in 12 intensive care patients. According to national surveillance reports in Turkey, linezolid resistance rates are reported as $0-2.3 \%$ for $S$. aureus, and Staphylococcus isolates with reduced susceptibility or resistance to linezolid have not been identified in many local studies $^{[6,7,24-27]}$.

Aktaş et al. ${ }^{[28]}$ reported two linezolid-resistant VRE isolates (2\%) for the first time in Turkey in 2012, and determined that the linezolid $\mathrm{MIC}_{50}$ and $\mathrm{MIC}_{90}$ values were 4 and 4 , respectively, while MIC range was 1-16 mg/l. According to Clinical and Laboratory Standards Institute (CLSI) standards ${ }^{[37]}$ (linezolid MIC threshold values of $\geq 8$ for resistance, 4 for intermediate,

Table 1. Distribution of isolates by sample type

\begin{tabular}{|c|c|c|c|c|c|c|c|}
\hline & & ${ }^{*} \mathrm{SST}$ & Respiratory & ${ }^{+} \mathrm{SBF}$ & Urine & Stool & Catheter \\
\hline \multirow{3}{*}{ VRE $(n=38)$} & Group 1 & 7 & 0 & 2 & 4 & 0 & 0 \\
\hline & Group 2 & 6 & 1 & 0 & 10 & 1 & 0 \\
\hline & Group 3 & 3 & 0 & 0 & 3 & 0 & 1 \\
\hline \multirow{3}{*}{ MRSA $(n=67)$} & Group 4 & 10 & 5 & 3 & 2 & 0 & 0 \\
\hline & Group 5 & 11 & 3 & 2 & 1 & 0 & 3 \\
\hline & Group 6 & 13 & 4 & 1 & 0 & 0 & 9 \\
\hline
\end{tabular}

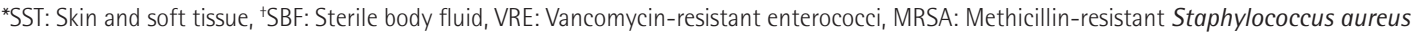

Table 2. Linezolid minimum inhibitor concentration (MIC), $\mathrm{MIC}_{50}$, and $\mathrm{MIC}_{90}$ values and $\mathrm{MIC}$ ranges in vancomycin-resistant enterococci and methicillin-resistant Staphylococcus aureus isolates

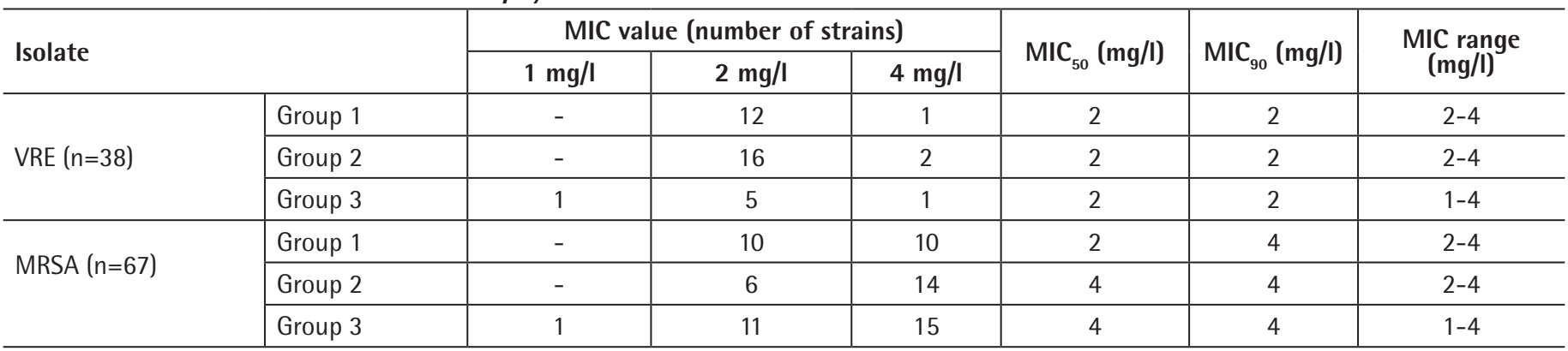

MIC: Minimum inhibitor concentration, VRE: Vancomycin-resistant enterococci, MRSA: Methicillin-resistant Staphylococcus aureus 
$\leq 2$ for susceptibility), $66 \%$ of the isolates were intermediate and $32 \%$ were susceptible. In another study based on CLSI standards, Iraz et al. ${ }^{[29]}$ reported that two enterococci isolates were intermediate and three (2\%) were resistant to linezolid. Although no resistance was detected in most previous studies, it was reported that resistance may emerge during linezolid use $^{[22,30,31]}$. Rates of linezolid resistance in studies performed in Turkey are shown in Table 3 $3^{[22,24-26,28-30,32,33] \text {. }}$

According to data from Turkey included in the 2014 and 2018 Central Asian and Eastern European Surveillance of Antimicrobial Resistance (CAESAR) reports, linezolid resistance rates fell from $2 \%$ to $0 \%$ in invasive $S$. aureus isolates, from $2 \%$ to $0 \%$ in E. faecalis isolates, and from $4 \%$ to $1 \%$ in E. faecium isolates ${ }^{[7,34]}$. Similarly, in Turkey HAI-net 2016 and 2017 reports, linezolid resistance rates classified by infection type declined in enterococci, but the increase in $S$. aureus was a notable contrast to the CAESAR reports (Table 4$)^{[35,36]}$. This difference may be attributable to the different sample groups in the two studies (only blood and cerebrospinal fluid isolates were evaluated in CAESAR).

In the present study, linezolid $\mathrm{MIC}_{50}$ and $\mathrm{MIC}_{90}$ values for both strains (2-4 mg/l and 4-4 mg/l) were higher than in most of the studies cited above. This may be due to probable more common use of linezolid over the years. In publications from Turkey, it appears that CLSI standards were generally used as evaluation criteria in studies investigating linezolid MIC values in VRE or MRSA isolates (Table 3). Although we found similar MIC values, our results differed from those that used CLSI criteria in that all isolates in our study were susceptible to linezolid, because we evaluated our results based on EUCAST standards. While a MIC value of $4 \mathrm{mg} / \mathrm{l}$ for linezolid is in the intermediate category in the CLSI classification, it is considered to be susceptible according to EUCAST ${ }^{[8,37]}$.

Our use of the broth microdilution method, which is the reference method to identify linezolid MIC, and evaluation of the results based on current EUCAST criteria provided more objective and valuable data. However, analyzing larger numbers of isolates and possibly organizing multicenter studies may yield more reliable data and more significant results when monitoring resistance.

\section{Conclusion}

Since linezolid became clinically available, there have been few reports of reduced susceptibility to it, which is very encouraging in the current era of descending antibiotic treatment options. Our investigation of temporal changes in linezolid MIC in VRE

Table 3. Rates of linezolid resistance in studies conducted in Turkey

\begin{tabular}{|c|c|c|c|c|c|c|c|c|c|c|}
\hline & \multicolumn{2}{|c|}{$\mathrm{MIC}_{50}$} & \multicolumn{2}{|c|}{$\mathrm{MIC}_{90}$} & \multicolumn{2}{|c|}{ MIC ranges } & \multicolumn{2}{|c|}{$\begin{array}{l}\text { Linezolid } \\
\text { resistance (\%) }\end{array}$} & \multirow{2}{*}{ Method/criteria } & \multirow{2}{*}{ Year/region } \\
\hline & VRE & MRSA & VRE & MRSA & VRE & MRSA & VRE & MRSA & & \\
\hline Efe et al. ${ }^{[19]}$ & 0.75 & 1.5 & 1.5 & 2 & $0.25-2$ & $0.25-3$ & $\% 0$ & $\% 0$ & E-test/CLSI & 2009 Bursa \\
\hline Aktaş et al. ${ }^{[24]}$ & 4 & - & 4 & - & $1-16$ & - & $\% 2$ & - & Broth microdilution/CLSI & 2007 İstanbul \\
\hline Iraz et al. ${ }^{[25]}$ & - & - & - & - & - & - & $\% 2$ & - & Vitek-2/CLSI & 2012 İstanbul \\
\hline Özseven et al. ${ }^{[26]}$ & - & - & - & - & - & - & $\% 4$ & - & Disc diffusion/CLSI & 2011 Isparta \\
\hline Çıkman et al..$^{[22]}$ & - & 0.75 & - & 1 & - & $0.125-1.5$ & - & $\% 0$ & E-test/CLSI & 2014/Multicenter \\
\hline Yıldız et al. ${ }^{[21]}$ & - & 2 & - & 2 & - & - & - & $\% 0$ & Agar dilution/CLSI & 2014/Multicenter \\
\hline Cesur et al. ${ }^{[23]}$ & - & 0.38 & - & 0.50 & - & - & - & $\% 0$ & E-test/CLSI & 2009/Multicenter \\
\hline Parlak et al. ${ }^{[29]}$ & 0.75 & - & 1.5 & - & $0.047-2$ & - & $\% 0$ & - & E-test/CLSI & 2011/Van \\
\hline Zencir et al. ${ }^{[32]}$ & - & 0.5 & - & 1 & - & $0.25-1$ & - & $\% 0$ & E-test/CLSI & 2013 İzmir \\
\hline
\end{tabular}

MIC: Minimum inhibitor concentration, VRE: Vancomycin-resistant enterococci, MRSA: Methicillin-resistant Staphylococcus aureus, CLSI: Clinical and Laboratory Standards Institute

Table 4. Rates of linezolid resistance in S. aureus, E. faecium, and E. faecalis according to the type of healthcare-associated infection (\%) (Healthcare-Associated Infections Surveillance Network-net 2016-2017 national data for Turkey) ${ }^{[35,36]}$

\begin{tabular}{l|c|c|c|c|c|c}
\hline \multirow{2}{*}{} & \multicolumn{2}{|c}{ S. aureus } & \multicolumn{2}{c}{ E. faecium } & \multicolumn{2}{c}{ E. fecalis } \\
\cline { 2 - 7 } & $\mathbf{2 0 1 6}$ & $\mathbf{2 0 1 7}$ & $\mathbf{2 0 1 6}$ & $\mathbf{2 0 1 7}$ & $\mathbf{2 0 1 6}$ & $\mathbf{2 0 1 7}$ \\
\hline Pneumonia & $\% 1.82$ & $\% 2.6$ & $\% 0$ & $\% 0$ & $\% 0$ & $\% 0$ \\
\hline Urinary tract infection & $\% 0$ & $\% 2,08$ & $\% 2.4$ & $\% 1.32$ & $\% 2.53$ & $\% 1.88$ \\
\hline Bloodstream infection & $\% 2,86$ & $\% 3,39$ & $\% 3.09$ & $\% 3.05$ & $\% 1.37$ & $\% 0.76$ \\
\hline Surgical site infection & $\% 1,19$ & $\% 1$ & $\% 2.7$ & $\% 1.04$ & $\% 3.81$ & $\% 1.41$ \\
\hline
\end{tabular}


and MRSA isolates revealed no linezolid-resistant strains, but we observed a significant increase in $\mathrm{MIC}_{50}$ and $\mathrm{MIC}_{90}$ values compared with other studies conducted in Turkey. Linezolid is one of the few potentially effective treatment options for resistant Gram-positive infections. Hence, clinicians' goal should be to maintain the low resistance rates by practicing rational antibiotic use and prevent the development of resistance through close monitoring.

\section{Ethics}

Ethics Committee Approval: Retrospective study.

Informed Consent: Retrospective study.

Peer-review: Externally and internally peer-reviewed.

\section{Authorship Contributions}

Concept: S.G., D.D., Design: S.G., D.D., Data Collection or Processing: S.G., F.Z.D., Analysis or Interpretation: S.G., F.Z.D., Literature Search: S.G., Writing: S.G., D.D.

Conflict of Interest: No conflict of interest was declared by the authors.

Financial Disclosure: The authors received no financial support from any institution or individual for this study.

\section{References}

1. Mendes RE, Castanheira M, Farrell DJ, Flamm RK, Sader HS, Jones RN. Longitudinal (2001-14) analysis of enterococci and VRE causing invasive infections in European and US hospitals, including a contemporary (201013) analysis of oritavancin in vitro potency. J Antimicrob Chemother. 2016;71:3453-8.

2. Patel SN, Memari N, Shahinas D, Toye B, Jamieson FB, Farrell DJ. Linezolid resistance in Enterococcus faecium isolated in Ontario, Canada. Diagn Microbiol Infect Dis. 2013;77:350-3.

3. Bialvaei AZ, Rahbar M, Yousefi M, Asgharzadeh M, Samadi Kafil H. Linezolid: a promising option in the treatment of Gram-positives. J Antimicrob Chemother. 2016;72:354-64.

4. Mendes RE, Deshpande LM, Jones RN. Linezolid update: Stable in vitro activity following more than a decade of clinical use and summary of associated resistance mechanisms. Drug Resist Updat. 2014;17:1-12.

5. Mendes RE, Farrell DJ, Sader HS, Streit JM, Jones RN. Update of the telavancin activity in vitro tested against a world wide collection of Grampositive clinical isolates (2013), when applying the revised susceptibility testing method. Diagn Microbiol Infect Dis. 2015;81:275-9.

6. Çöplü N, Şimşek H, Gür D, Gözalan A, Hasdemir U, Gülay Z, Bayramoğlu G, Aydemir \$̧, Gürler N, Eyigör M, Perçin D, Aktaş D. The first results of national antimicrobial resistance surveillance system in Turkey. Turk Hij Den Biyol Derg. 2018;75:333-44.

7. Halk Sağlığı Genel Müdürlüğü (HSGM). Last Accessed date: 6 December 2018. Available from: https://hsgm.saglik.gov.tr/depo/birimler/Mikrobiyoloji_ Referans_Laboratuvarlari_ve_Biyolojik_Urunler_DB/uamdss/52238_WHO_ CAESAR_AR_2018_low_V7_web_2.pdf

8. European Committee on Antimicrobial Susceptibility Testing (EUCAST). Break point tables for interpretation of MICs and zone diameters, Version 8.0, 2018. Last Accessed date: 27 June 2018. Available from: http://www. eucast.org/clinical_breakpoints/
9. Aydemir Ş, Çöplü N, Gülay Z, Gür D, Hasdemir U, Karahan ZC, Karatuna O, Kayacan ZÇ, Söyletir G. Antibiyotik duyarlılık testleri EUCAST: uygulama, yorum ve uzman kurallar, Minimum İnhibitör Konsantrasyon Saptama Yöntemleri: Sıvı Dilüsyon, Agar Dilüsyon ve Antibiyotik Gradiyent testi (G-test), Türk Mikrobiyoloji Cemiyeti Dergisi. 2016;46(Özel Sayı):S11-S25.

10. Ulusal Hastane Enfeksiyonları Sürveyans Ağı Özet Raporu 2015. Last Accessed date: 15 January 2019. Available from: https://infline.saglik.gov. tr/Dokuman/Raporlar/UHESA2015.pdf

11. Ulusal Hastane Enfeksiyonları Sürveyans Ağı Özet Raporu 2016. Last Accessed date: 15 January 2019. Available from: https://infline.saglik.gov. tr/Dokuman/Raporlar/UHESA2016.pdf

12. Ulusal Hastane Enfeksiyonları Sürveyans Ağı Özet Raporu 2017. Last Accessed date: 15 January 2019. Available from: https://infline.saglik.gov. tr/Dokuman/Raporlar/USH\%C4\%BOESA\%20\%C3\%96ZET\%20RAPOR\%20 2017.pdf

13. Livermore DM. Linezolid in vitro: mechanism and antibacterial spectrum. J Antimicrob Chemother. 2003;51(Suppl 2):S9-S16.

14. Tsiodras S, Gold HS, Sakoulas G, Eliopoulos GM, Wennersten C, Venkataraman L, Moellering RC, Ferraro MJ. Linezolid resistance in a clinical isolate of Staphylococcus aureus. Lancet. 2001;358:207-8.

15. Taşova Y. Dirençli Current Therapy of Infectious Caused by Resistant GramPositive Bacteria. Yoğun Bakım Dergisi. 2012;10:147-64.

16. Sánchez Garcia M, De la Torre MA, Morales G, Peláez B, Tolón MJ, Domingo S, Candel FJ, Andrade R, Arribi A, García N, Martínez Sagasti F, Fereres J, Picazo J. Clinical Outbreak of Linezolid Resistant Staphylococcus aureus in Intensive Care Unit. JAMA. 2010;303:2260-4.

17. Endimiani $A$, Blackford $M$, Dasenbrook EC, Reed MD, Bajaksouszian $S$, Hujer AM, Rudin SD, Hujer KM, Perreten V, Rice LB, Jacobs MR, Konstan MW, Bonomo RA. Emergence of linezolid-resistant Staphylococcus aureus after prolonged treatment of cystic fibrosis patients in Cleveland, Ohio. Antimicrob Agents Chemother. 2011;55:1684-92.

18. Lazaris A, Coleman DC, Kearns AM, Pichon B, Kinnevey PM, Earls MR, Boyle B, O'Connell B, Brennan GI, Shore AC. Novel multiresistance cfr plasmids in linezolid-resistant methicillin resistant Staphylococcus epidermidis and vancomycin-resistant Enterococcus faecium (VRE) from a hospital outbreak: co-location of cfr and optrA in VRE. J Antimicrob Chemother. 2017;72:3252-7.

19. Smith T, Tamma PD, Do TB, Dzintars KE, Zhao Y, Cosgrove SE, Avdic E. Prolonged linezolid use is associated with the development of linezolidresistant Enterococcus faecium. Diagn Microbiol Infect Dis. 2018;91:161-3.

20. Santayana EM, Grim SA, Janda WM, Layden JE, Lee TA, Clark NM. Risk factors and out comes associated with vancomycin-resistant Enterococcus infections with reduced susceptibilities to linezolid. Diagn Microbiol Infect Dis. 2012;74:39-42.

21. Flamm RK, Mendes RE, Hogan PA, Streit JM, Ross JE, Jones RN. Linezolid surveillance results for the United States (LEADER surveillance program 2014). Antimicrob Agents Chemother. 2016;60:2273-80.

22. Efe Ş, Sınırtaş M, Özakın C. In vitro susceptibility to linezolid in methicillinresistant Staphylococcus aureus and vancomycin-resistant enterococcus strains. Mikrobiyol Bul. 2009;43:639-43.

23. Morales G, Picazo JJ, Baos E, Candel FJ, Arribi A, Peláez B, Andrade R, de la Torre MA, Fereres J, Sánchez-Garcia M. Resistance to Linezolid Is Mediated by the cfr Gene in the First Report of an Outbreak of Linezolid-Resistant Staphylococcus aureus. Clin Infect Dis. 2010;50:821-5.

24. Yıldız Ö, Çoban AY, Şener AG, Coşkuner $S A$, Bayramoğlu G, Güdücüoğlu H, Özyurt M, Tatman-Otkun M, Karabiber N, Özkütük N, Aktepe O, Öncü $\mathrm{S}$, Arslan U, Bozdoğan B. Antimicrobial Susceptibility and Resistance Mechanisms of Methicillin Resistant Stapylococcus aureus Isolated from 12 Hospitals in Turkey. Ann Clin Microbiol Antimicrob. 2014;13:44. 
25. Çıkman A, Aydın M, Gülhan B, Parlak M, Gültepe B, Kalaycı Y, Bayındır Bilmen F, Solmaz $S$, Özekinci T. Investigation of Antibiotic Resistance Patterns and Reduced Vancomycin Susceptibilities of Methicillin-Resistant Staphylococcus aureus Isolates: A Multi-Center Study. Mikrobiyol Bul. 2015;49:240-8.

26. Cesur S, Irmak H, Simşek H, Çöplü N, Kılıç H, Arslan U, Bayramoğlu G, Baysan BO, Gülay Z, Hoşoğlu S, Berktaş M, Gencer S, Demiröz AP, Esen B, Karabiber $N$, Aydın F, Yalçın AN. Evaluation of antibiotic susceptibilities and VISAVRSA rates among MRSA strains isolated from hospitalized patients in intensive care units of hospitals in seven provinces of Turkey. Mikrobiyol Bul. 2012;46:352-8.

27. Dokutan A, Hacıseyitoğlu D, Çağ Y, Pazar Yıldırım E, Batırel A, Özer S, Gönüllü $\mathrm{N}$. Linezolid resistance and antimicrobial susceptibility in staphylococci isolated from clinical specimens. Ortadoğu Tıp Dergisi. 2017;9:19-23.

28. Aktaş G, Bozdoğan B, Derbentli ş. In vitro Activity of Linezolid and Dalbavancin Against Vancomycin-Resistant Enterococci. Mikrobiyol Bul. 2012;46:359-65.

29. Iraz M, Ceylan A, Akkoyunlu Y. Antibiotic Susceptibility of Enterococcus Strains Isolated from Various Clinical Samples ANKEM Derg. 2012;26:17680.

30. Özseven AG, Sesli Çetin E, Cicioğlu Arıdoğan B, Çiftçi E, Özseven L. Antimicrobial Susceptibility of Enterococci Isolated from Various Clinical Specimens ANKEM Derg. 2011;25:256-62.

31. Yenişehirli G, Yenişehirli A, Bulut $Y$, Özveren G. Antimicrobial Resistance of Enterococci Isolated From Urine Cultures. Klimik Dergisi. 2016;29:112-6.
32. Parlak M, Binici I, Çıkman A, Karahocagil MK, Bayram $Y$, Berktaş $M$. Investigation of linezolid, tigecycline and daptomycin susceptibility in vancomycin-resistant enterococci using E-test method. Dicle Medical Journal. 2014;41:534-7.

33. Zencir M, Arı A, Yılmaz N, Avcı M, Çalık Ş, Coşkuner SA, Bal F, Ağuş N. Metisiline Dirençli Staphylococcus aureus suşlarının Antibiyotiklere Duyarlıı̆̆ı, Hastaların Klinik Özellikleri ve Mortaliteyi Etkileyen Faktörler. ANKEM Derg. 2016;30:18-23.

34. Halk Sağlığı Genel Müdürlüğü (HSGM). Last Accessed date: 6 December 2018. Available from: https://hsgm.saglik.gov.tr/depo/birimler/ Mikrobiyoloji_Referans_Laboratuvarlari_ve_Biyolojik_Urunler_DB/uamdss/ CAESAR_Annual_Report_2014_I_Ik_Rapor_.pdf

35. Ulusal Sağlık Hizmeti İlişkili Enfeksiyonlar Sürveyans Ağı Etken Dağııımı ve Antibiyotik Direnç Raporu 2016. Last Accessed date: 15 January 2019. Available from: https://infline.saglik.gov.tr/Dokuman/Raporlar/2016\%20 Etken $\% 20$ Da $\% C 4 \% 9 F \% C 4 \% B 1 / \% C 4 \% B 1$ m\%20ve\%20Antibiyotik $\% 20$ Diren\%C3\%A7\%20\%C3\%96zet\%20Raporu.pdf

36. Ulusal Sağlık Hizmeti İlişkili Enfeksiyonlar Sürveyans Ağı Etken Dağılımı ve Antibiyotik Direnç Raporu 2017. Last Accessed date: 15 January 2019. Available from: https://infline.saglik.gov.tr/Dokuman/Raporlar/2017\%20 Etken $\% 20$ Da $\% C 4 \% 9 F \% C 4 \% B 1 / \% C 4 \% B 1$ m\%20ve\%20Antibiyotik $\% 20$ Diren\%C3\%A7\%20\%C3\%96zet\%20Raporu.pdf

37. Clinical and Laboratuary Standards Institue (CLSI). CLSI Performance Standards for Antimicrobial Susceptibility Testing; Twenty-Third Informational Standards. PA, CLSI. 2013;(Suppl):M100-S23. 